\title{
Oryeong-san Ameliorates High Glucose-induced Mesangial Cell Proliferation
}

\author{
Jung Joo Yoon ${ }^{1,2,3} \cdot$ Yun Jung Lee ${ }^{1,2,3}$. So Min Lee ${ }^{1,2,3} \cdot$ Dae Hwan Kim¹,2,3. \\ Ho Sub Lee ${ }^{1,2,3} \cdot$ Dae Gill Kang ${ }^{1,2,3^{*}}$ \\ ${ }^{1}$ College of Oriental Medicine. \\ ${ }^{2}$ Professional Graduate School of Oriental Medicine \\ ${ }^{3}$ Hanbang Body-fluid research center, Wonkwang University
}

\section{오령산에 의한 고포도당 유도 사구체간질세포 이상증식 개선효과

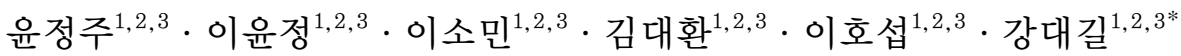 \\ ${ }^{1}$ 한의과대학 생리학교실 · ${ }^{2}$ 원광대학교 한의학전문대학원 · \\ ${ }^{3}$ 한방체액조절연구센터}

\begin{abstract}
Objectives : Diabetic nephropathy is associated with morbidity and mortality of diabetes mellitus patients. Mesangial cell proliferation is known as the major pathologic features such as glomerulosclerosis. Oryeong-san, Korean formula, is widely used for the treatment of nephrosis, edema, and uremia. Oryeong-san is composed of five herbs: Alismatis Rhizoma, Polyporus, Atractylodis Rhizoma Alba, Hoelen, and Cinnamomi Cortex.

Methods : The present study was performed to investigate potent inhibitory effect of Oryeong-san on high glucose (HG)-induced rat mesangial cells (RMC) proliferation.
\end{abstract}


Results : RMC proliferation under $25 \mathrm{mM}$ glucose was significantly accelerated compared with $5.5 \mathrm{mM}$ glucose, which was inhibited by Oryeong-san in dose dependent manner. Pre-treatment of Oryeong-san induced down-regulation of cyclins/CDKs and up-regulation of CDK inhibitor, p21waf1/cip1 and p27kip1 expression. In addition, Oryeong-san reduced HG-induced RMC proliferation by suppressed the mitogen-activated protein kinase (MAPK) phospholyration such as extracellular signal regulated kinase (ERK), Jun $\mathrm{N}$-terminal Kinase (JNK), and p38. Oryeong-san significantly suppressed HG-induced ROS production.

Conclusions : Oryeong-san consequently inhibited HG-induced mesangial cell proliferation through the inhibition of MAPK and ROS signaling pathway. These results suggest that Oryeong-san may be effective in the treatment of renal dysfunction leading to diabetic nephropathy.

Keyword : Oryeong-san; Mesangial cell; Proliferation; Diabetic nephropathy

\section{I . Introduction}

Diabetes is the leading cause of end-stage renal failure, and much of the morbidity and mortality of diabetes can be attributed to nephropathy. The pathological changes of diabetic nephropathy include kidney hypertrophy, glomerulus and tubular basement membrane thickening, tubular interstitial fibrosis and arteriosclerosis. Increased mesangial cell proliferation is one of the major pathologic features in the early stage of diabetic nephropathy ${ }^{1)}$. Knowledge of the role of rat mesangial cell (RMC) in normal glomeruli and of their response to pathological stimuli is crucial to the understanding of these disease processes $^{2)}$. Mesangial cells, which are contractile, smooth muscle-like cells located in the intercapillary space of the glomerular tufts, are thought to be the primary producers of mesangial extracellular matrix (ECM) constituents. The mesangial matrix is normally composed of various macromolecules, including fibronectin, laminin, collagen, and thrombospondin, as well as various proteoglycans ${ }^{3)}$.

In many cells, transit through the G1 phase of the cell cycle and entry into the $\mathrm{S}$-phase require

\footnotetext{
*Corresponding author : D. G. Kang, College of Oriental

Medicine, Wonkwang University. Iksan.

- Tel : 063-850-6933 - Fax : 063-850-7260

·Email : dgkang@wku.ac.kr

- 접수 2013/10/16 • 수정 2013/11/9 ・ 채택 2013/11/15
}

the binding and activation of cyclin/CDK complexes, predominantly cyclin D1/CDK4 and cyclin E/CDK2 ${ }^{4)}$. Some studies have shown a role for CDKI p21waf1/ cip1 and p27kip1 in the proliferation of renal mesangial cell ${ }^{5-7)}$. Mitogen-activated protein kinases (MAPK) including the extracellular signalregulated protein kinase-1/2 (ERK 1/2), stressactivated c-Jun $\mathrm{N}$-amino terminal kinase (JNK), and p38 MAPK play a key role in the intracellular signal transduction cascade to integrate the transcription of genes responsible for a variety of cellular responses relevant to diabetic nephropathy such as cell growth, differentiation, and ECM synthesis $^{8)}$. There are few data on the effects of pharmacological intervention on mesangial cell proliferation in diabetic nephropathy.

Oryeong-san (Wulingsan), composed of five herbs: Alismatis Rhizoma, Polyporus, Atractylodis Rhizoma Alba, Hoelen, and Cinnamomi Cortex, originally recorded in "Treatise on Cold Damage Diseases" (Shanghanlun). Oryeong-san has been reported to possess renal protective effects from renal diseases such as diabetes induced renal damage ${ }^{9)}$, nephrocalcinosis ${ }^{10)}$, and adriamycin-induced nephrotic syndrome in experimental models ${ }^{11)}$. Recently, it was reported that Oryeong-san induced natriuresis and diuresis along with an inhibition of reninangiotensin-aldosterone system ${ }^{12,13)}$. 
Therefore, the present study was performed to determine the possible effects of Oryeong-san decoction on the proliferation of primary $\mathrm{RMC}$ in response to high glucose (HG).

\section{Material and Method}

\section{Materials}

D-glucose, collagenase (type IV), and all other reagents were purchased from Sigma Chemical Company (St. Louis, MO, USA). CM-H2DCFDA was purchased from Invitrogen, Inc (Eugene, OR). Mouse monoclonal antibodies to $\mathrm{p} 21^{\mathrm{waf} 1 / \mathrm{cip} 1}$, p2 $7^{\mathrm{kip} 1}$, JNK, ERK and p38 MAPK were obtained from Santa Cruz Biotechnology (Santa Cruz, CA, USA). Rabbit polyclonal antibodies to CDKs, Cyclins, $\beta$ -actin were purchased from Santa Cruz Biotechnology. Goat anti-rabbit IgG and goat antimouse IgG were purchased from Jackson Immunoresearch (West Grove, PA, USA).

\section{Preparation of Oryeong-san}

The formula of Oryeong-san consists of five herbs including Alismatis Rhizoma, Polyporus, Atractylodis Rhizoma Alba, Hoelen, and Cinnamomi Cortex were mixed according to the ratio of $5: 3: 3: 3: 1$ in weight and ground into a crude powder. The Oryeong-san (281 g) was boiled with $2 \mathrm{~L}$ of distilled water at $100^{\circ} \mathrm{C}$ for $2 \mathrm{~h}$. The extract was centrifuged at $990 \times \mathrm{g}$ for $20 \mathrm{~min}$ at $4^{\circ} \mathrm{C}$ and resulting supernatant was lyophilized to produce a powder $(65.67 \mathrm{~g})$, which was then kept at $-70^{\circ} \mathrm{C}$ until using this experiment.

\section{Cell cultures}

Rat mesangial cell were isolated and cultured by employing a standard collagenase digestion method ${ }^{14)}$. Briefly, male Sprague-Dawley rats weighing 150-
$175 \mathrm{~g}$ were anesthetized and their kidneys were removed. Renal cortical tissues were separated from the medulla and minced in D-Hank's balanced buffer using sterile conditions. Minced renal cortical tissues were filtered through 220, 100, and then 76 $\mathrm{mm}$ stainless steel mesh filters and subsequently digested in $0.1 \%$ collagenase (type IV) solution at $37^{\circ} \mathrm{C}$ for $30 \mathrm{~min}$. After centrifuging at $1,000 \mathrm{rpm} /$ $\min$ for $10 \mathrm{~min}$ at room temperature, pellets were re-suspended with 5.5 mM glucose DMEM supplemented with $15 \%$ FBS, $100 \mathrm{U} / \mathrm{mL}$ penicillin, 100 $\mathrm{mg} / \mathrm{ml}$ streptomycin, and $5 \mathrm{mg} / \mathrm{ml}$ bovine insulin. The dispersed glomeruli were placed in $100 \mathrm{~mm}$ plastic dishes with the same culture medium and incubated in a humidified incubator at $37^{\circ} \mathrm{C}$ under $95 \%$ air and $5 \% \mathrm{CO}_{2}$. The culture medium was changed every 3 days. Cell outgrowth from glomeruli was observed every 2-3 days after seeding, which would reach confluence after 30 days. The cells from passages 5-10 were employed in the current study.

\section{Cell viability and proliferation}

The cells were plated in culture flasks and incubated approximately $80 \%$ confluent. Cells were stimulated with HG in the presence or absence of indicated concentration of Oryeong-san (1-50 $\mu$ $\mathrm{g} / \mathrm{ml}$ ) for $24 \mathrm{~h}$. The assay was dependent on the reduction of tetrazolium salt (MTT) by mitochondrial dehydrogenase of viable cells into dark violet formazan product which was then solubilized in $100 \mu 1$ of Dimethyl sulphoxide (DMSO). Viability of the cells was determined using a colorimetric assay at $540 \mathrm{~nm}$ (Bio-Tek Instrument Inc., Vermont, USA).

\section{Migration assay}

The effect of Oryeong-san on the migration of RMC was evaluated using a wound healing assay. .Briefly, RMC were grown to confluence 6-well culture plates. A scratch was made with a yellow 
tip and then rat mesangial cell were incubated for $24 \mathrm{~h}$ with or without $\mathrm{HG}(25 \mathrm{mM})$ and various Oryeong-san in serum free media. After incubation, cells were washed 3 times with ice-cold PBS. The cells fixed by methyl alcohol for $5 \mathrm{~min}$ and cells were stained with hematoxylin and eosin. The microscopic photographs of migrated cells were kindly producted by fluorescence microscope (Axiovision 4, Zeiss, Germany). In each group, three duplicate wells were assayed, and each assay was conducted at least three times.

\section{Western blot analysis}

Cell homogenates (40 $\mathrm{g}$ of protein) were separated on $10 \%$ SDS-polyacrylamide gel electrophoresis and transferred to nitrocellulose paper. Blots were then washed with $\mathrm{H}_{2} \mathrm{O}$, blocked with $5 \%$ skimmed milk powder in TBST [10 mM Tris-HCl ( $\mathrm{pH} 7.6), 150 \mathrm{mM} \mathrm{NaCl}, 0.05 \%$ Tween-20] for $1 \mathrm{~h}$ and incubated with the appropriate primary antibody at dilutions recommended by the supplier. Then the membrane was washed, and primary antibodies were detected with goat anti-rabbit-IgG conjugated to horseradish peroxidase, and the bands were visualized with enhanced chemiluminescence (Amersham, Buckinghamshire, UK). Protein expression levels were determined by analyzing the signals captured on the nitrocellulose membranes using the Chemi-doc image analyzer (Bio-Rad, Hercules, CA, USA).

\section{Determination of hydrogen peroxide}

The dye CM-H2DCFDA ( $2^{\prime}, 7^{\prime}$-dichlorodihydrofluorescein diacetate) has been used to measure intracellular generation of ROS. Rat mesangial cell were washed twice with phosphate buffered saline (PBS) and incubated $30 \mathrm{~min}$ at $37^{\circ} \mathrm{C}$ with $10 \mu$ M DCF-DA (Molecular Probes, Eugene, OR, USA), a nonfluorescent compound that freely permeates cells. After being washed with cold PBS twice, the cells were trypsinized from the culture flask. And then centrifugation at $800 \times \mathrm{g}$ for 2 min at room temperature, the supernatant was removed. Collected cells were suspended in PBS of $500 \mu \mathrm{l}$. The cells were analyzed by flow cytometry (FACScalibur, BD, San Diego, CA, USA).

\section{Intracellular ROS production assay}

The fluorescent probe CM-H2DCFDA was used to determine the intracellular generation of ROS by HG. Briefly, the confluent RMC in the 24-well culture plates were pretreated with Oryeong-san for $24 \mathrm{~h}$. After removing the Oryeong-san from the wells, RMC were incubated with $10 \mu \mathrm{M} \mathrm{CM-}$ H2DCFDA for $30 \mathrm{~min}$. The RMC were then stimulated with HG, and the fluorescence intensity (relative fluorescence units) was measured at an excitation and emission wavelength of $485 \mathrm{~nm}$ and $530 \mathrm{~nm}$, respectively, using a spectrofluorometer (F-2500, Hitachi, Tokyo, Japan).

\section{Statistical analysis}

Values were expressed as a mean \pm S.E., the data were assessed by Sigma 10.0 software. Unpaired Student's t test was used for comparison between two groups. For multiple comparisons, data were analyzed by one-way ANOVA with Post Hoc Multiple Comparisons. The independent experiments were performed at least 3 times with similar results. $\mathrm{P}<0.05$ was considered as statistically significance.

\section{Results}

1. Effect of Oryeong-san on HG-induced mesangial cell Proliferation and migration

In the experiment to determine the effect of high glucose $(25 \mathrm{mM})$ on RMC proliferation, this study examined cell proliferation using MTT. Exposure of 


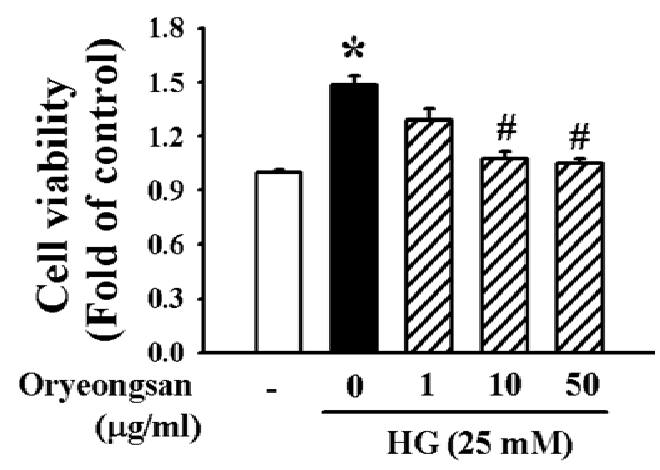

Figure 1. Effect of Oryeong-san on HG-induced cultured RMC proliferation.

RMC were incubated for $24 \mathrm{~h}$ with or without $\mathrm{HG}$ and Oryeong-san, and then cell viability and proliferation were assessed using a MTT assay. Results are expressed as the mean \pm S.E. from four independent experiments. ${ }^{*} p<0.05$, vs. control; $\# p<0.05$, vs. HG alone.

RMC to $25 \mathrm{mM}$ D-glucose for $24 \mathrm{~h}$ induced cell proliferation (Fig. 1). HG-induced increase of cell proliferation was significantly reduced by pretreatment of Oryeong-san. To rule out the involvement of hyperosmolarity in $25 \mathrm{mM}$ glucose-induced increase of cell proliferation, L-glucose and D-mannitol with an equal concentration of glucose were added to RMC. D-mannitol (25 mM) and L-glucose (25 mM) did not affect cell proliferation (data not shown).

To investigate the effect of Oryeong-san on RMC migration, a wound-healing assay was performed in which the rate of wound closure (initial width $1 \mathrm{~mm}$ ) was measured in confluent cell monolayers. The wounds healed linearly over $24 \mathrm{~h}$ in the HGtreated cells. However, the speed of the wound edge was decreased significantly in a dose-dependent manner in the Oryeong-san pretreatment cells (Fig. 2). These results demonstrate that Oryeong-san has a protective effect on cell growth and renal proliferation in diabetes.

2. Effect of Oryeong-san on G1 cell-cycle related protein expression

Cell proliferation requires the coordinated inter-

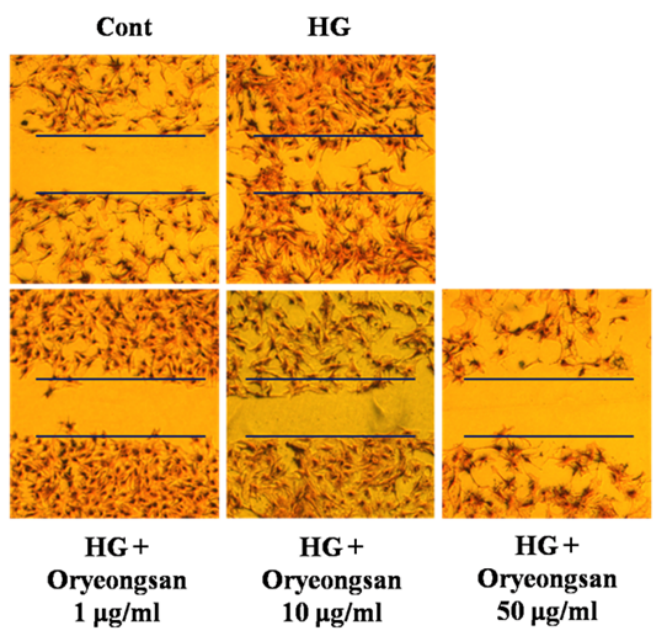

Figure 2. Effect of Oryeong-san on HG-induced RMC migration.

Representative photographs of migrating cells that received either control or Oryeong-san treatment. (a) control; (b) HG alone; (c) HG with Oryeong-san (1 $\mu \mathrm{g} / \mathrm{ml})$; (d) HG with Oryeong-san (10 $\mu \mathrm{g} / \mathrm{ml}) ;$ (e) HG with Oryeong-san $(50 \mu \mathrm{g} / \mathrm{ml})$. Each assay was conducted at least three times.

action of cyclins and cyclin-dependent kinases to drive cells through the cell cycle. Cyclin-dependent kinase inhibitors can bind cyclin-CDK complexes and cause G1 arrest. Using Western blotting, we analyzed the protein expressions of the cyclins and CDKs, which are known to regulate by $\mathrm{p} 21^{\mathrm{waf} 1 / \mathrm{cip} 1}$ and $\mathrm{p} 27^{\mathrm{kip} 1}$, following treatment with Oryeong-san. Incubation of RMC with Oryeong-san led to slightly decrease the levels of cyclin D1/E and CDK2/4 expression in HG status. In contrast, HG condition resulted in a reduction in the levels of p21waf1/ cip1 and p27kip1, CDK inhibitory protein. Pretreatment with Oryeong-san attenuated the HG-induced increases in cyclin D1/E, CDK2/4 and decreases in $\mathrm{p} 21^{\mathrm{waf} 1 / \mathrm{cip} 1}$ and $\mathrm{p} 27^{\mathrm{kip} 1}$ expression levels (Fig. 3A, B).

3. Effect of Oryeong-san on HG-induced MAPKs phosphorylation

Since the activation of JNK, ERK and p38 MAPK signaling is a key step in the proliferation process of a variety of cell types ${ }^{15)}$. Western blot analysis 
A.

B.

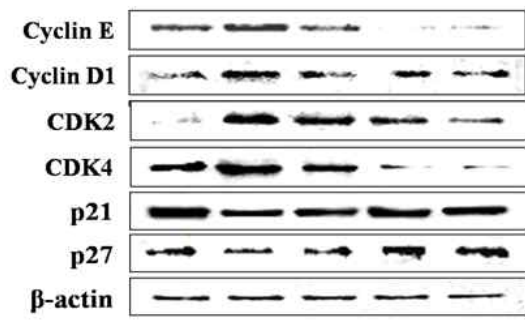

HG (25 mM) - + + + +

Oryeongsan

$(\mu \mathrm{g} / \mathrm{ml})$

$1 \quad 10 \quad 50$
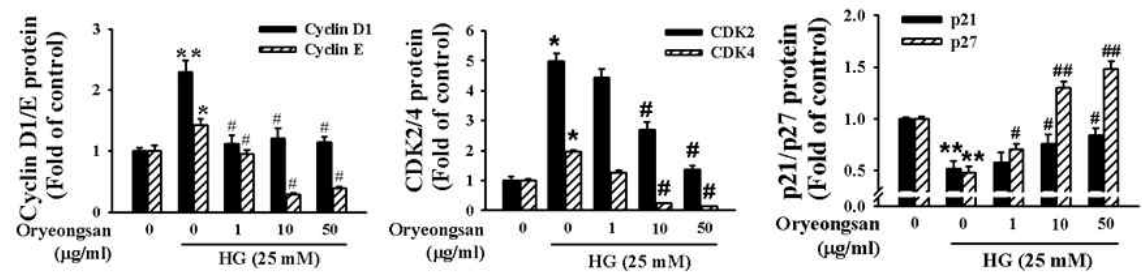

Figure 3. Effect of Oryeong-san on cell-cycle related protein expression.

(A) Cells ere stimulated with HG in the presence or absence of indicated concentration of Oryeong-san at $24 \mathrm{~h}$ and Western blot analysis was performed with antibodies specific for CyclinD1/E, CDK2/4, p21waf1/cip1, and p27kip1, respectively. Each electrophoretogram is representative of the results from five independent experiments. (B) Each value represents the means \pm S.E. of independent experiments. ${ }^{*} p<0.05,{ }^{* *} p<0.01$ vs. control; $\# p<0.05, \# p<0.01$ vs. HG alone.

A.

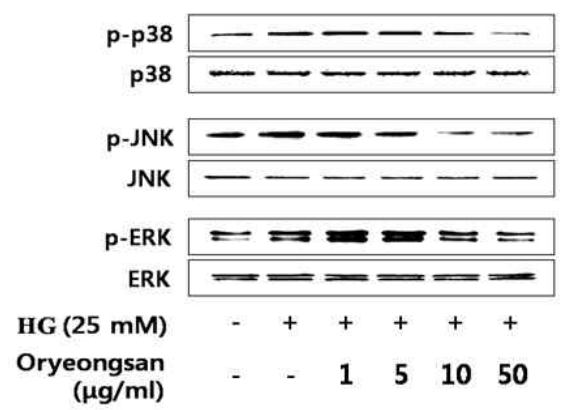

B.

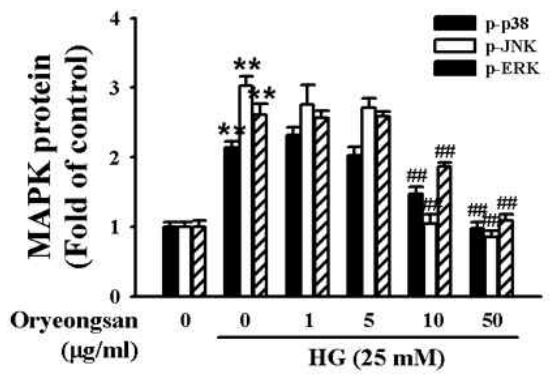

Figure 4. Effect of Oryeong-san on HG-induced the phosphorylation of MAPK.

Cells were treated with the indicated concentrations of Oryeong-san for $24 \mathrm{~h}$. And then cells were analyzed Western blot analysis for the p-ERK1/2, p-p38, p-JNK protein expressions. Each electrophoretogram is representative of the results from five independent experiments

was performed to evaluate the role of the active form (phosphorylated) of these signaling proteins in HGnduced proliferation. As shown in Figure 4, pretreatment of Oryeong-san decreased the phosphorylation level of JNK, ERK and p38 MAPK significantly under HG condition. These results reveal that MAPK family take part in the regulation of RMC proliferation. Thus, Oryeong-san improves HG-induced mesangial cell proliferation through inhibited MAPK signaling. 
A. (a)
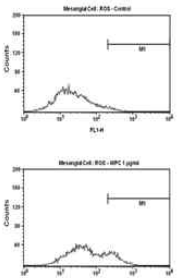

(d) (b)
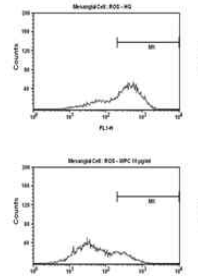

(e) (c)
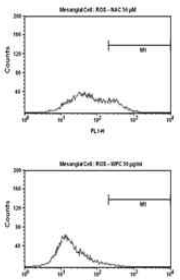

(f)
B.

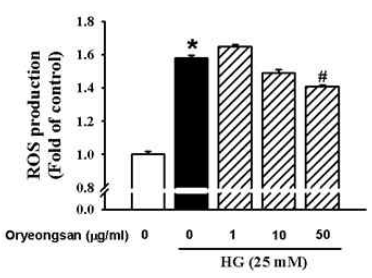

Figure 5. Effect of Oryeong-san on HG-induced ROS production.

(A) DCF-sensitive ROS assay were measured by FACS analysis. (a) control; (b) HG alone; (c) HG with NAC (50 $\mu$ $\mathrm{M})$; (d) HG with Oryeong-san $(1 \mu \mathrm{g} / \mathrm{ml})$; (e) HG with Oryeong- san $(10 \mu \mathrm{g} / \mathrm{ml}) ;(\mathrm{f}) \mathrm{HG}$ with Oryeong-san $(50$ $\mu \mathrm{g} / \mathrm{ml}$ ). (B) Alternatively, the relative ROS levels were quantified by fluorescence microplate. Each value represents the means \pm S.E. of three independent experiments.

${ }^{*} p<0.05$ vs. control; $\# p<<0.05$ vs. HG alone.

4. Effect of Oryeong-san on HG-induced ROS production

To investigate the effect of Oryeong-san on HG-induced oxidative stress, cells were collected and treated under $25 \mathrm{mM}$ glucose. Cells were treated with $\mathrm{HG}$ in the absence or presence of Oryeong-san (1-50 $\mu \mathrm{g} / \mathrm{ml})$. Cells were labeled with a cell-permeable fluorescent dye, CM-H2DCFDA and analyzed by flow cytometry or spectrofluorometer. Coincident with the Fluorescence-Activated Cell Sorting Analysis, Oryeong-san was compared with $\mathrm{N}$-acetyl-cysteine (NAC) $(50 \mu \mathrm{M})$, as an antioxidant (Fig. 5A). The data suggest that Oryeong-san inhibited HG-induced ROS production in a concentration-dependent manner. As shown in Figure $5 \mathrm{~B}$, intracellular ROS levels after $\mathrm{HG}$ treatment were higher than untreated cells (control). However, pretreatment with Oryeong-san significantly decreased HG-induced ROS levels.

\section{Discussion}

Herb, Acupuncture and Natural Medicine (HAN), one of the most ancient and revered forms of healing, has been used to diagnose, treat, and prevent disease for over 3,000 years. HAN is now used worldwide as an effective means of overcoming disease. Oryeong-san is a well-known blended traditional herbal medicine specifically for the treatment of body-fluid disorders.

In the current study, we provided the evidence for the inhibitory effect of Oryeong-san on HGinduced RMC proliferation. Diabetic nephropathy, a progressive kidney disease caused by angiopathy of capillaries in the kidney glomeruli, is one of the most severe complications of type I and type II diabetes, and has become a major cause of endstage renal disease ${ }^{16)}$. The earliest detectable change in the course of diabetic nephropathy is an expansion of the glomerular mesangium, which is caused by mesangial cell proliferation and excessive accumulation of ECM proteins ${ }^{17}$. Glomerular mesangial cells, an important member of renal glomerulus, play a major role not only in physiological functions but also in pathogenesis of kidney diseases ${ }^{18)}$.

In the present study, mesangial cell numbers were reduced by Oryeong-san treatment. In addition, migration of rat mesangial cell was also reduced by Oryeong-san in an in vitro mechanical injury assay. Cell cycle is an elementary process in vital movements of cells, and it has a close connection with the cell proliferation, differentiation and apoptosis. Progression of the cell cycle is regulated by the balance between the levels and activities 
of cyclin/CDK complexes and CDKIs. Some studies have shown a role for the CDKIs p21waf1/cip1 and p27kip1 in the proliferation of rat mesangial cell 5-7). Our results showed that Oryeong-san inhibited cyclinD1/CDK4 and cyclinE/CDK2 activities by increasing the expression of $\mathrm{p} 21^{\mathrm{waf} 1 / \mathrm{cip} 1}$ and $\mathrm{p} 27^{\mathrm{kip} 1}$ in rat mesangial cell following HG treatment. These results suggest that treatment with Oryeong-san induces a G0/G1 arrest in the cell cycle by increasing the expression of CDKIs, p21 ${ }^{\text {waf1/cip1 }}$ and p27 $7^{\text {kip1 }}$, and decreasing CDK2/4 activities.

Numerous evidences have suggested that the MAPK family including ERK1/2, p38 MAPK and JNK play pivotal roles in the development of diabetic nephropathy ${ }^{19)}$. This study observed that HG enhanced phosphorylation of all MAPK family such as ERK, p38 MAPK, and JNK. Cell proliferation was markedly increased through the activation of p38 MAPK signaling pathway in mesangial cells under HG condition ${ }^{20)}$. Aminoguanidine and adrenomedullin reportedly could exert their renal protective effects via inhibiting p38 MAPK phosphorylation ${ }^{21}$. In recent years, it has been reported that HG enhances mesangial cell proliferation and fibronectin expression through $\mathrm{JNK} / \mathrm{NF}-\kappa \mathrm{B} / \mathrm{NADPH}$ oxidase/ROS pathway, which was inhibited by resveratrol ${ }^{22)}$. On the other hand, in mesangial cell, HG increased the levels of phosphorylated ERK but not phosphorylated p38 or phosphorylated JNK ${ }^{23)}$. In this study, HG induced all MAPK family phophrylation in cultured mesangial cell. This discrepancy might be dependent to the specificity of HG concentration (25 mM vs. $35 \mathrm{mM}$ ) or experimental models (primary culture vs. cell line). Moreover, Oryeong-san significantly decreased MAPK phosphorylation, suggesting that Oryeong-san inhibited HG-induced MAPK activities.

These results demonstrate that HG enhances mesangial cell proliferation through MAPK phosphorylation, which was inhibited by Oryeong-san.

Oxidative stress has been known to play an important role in the development and progression of diabetic nephropathy, and ROS is a direct consequence of hyperglycemia. ROS activates other signaling molecules, such as protein kinas $\mathrm{C}$ (PKC), MAPK and transcription factors including $\mathrm{NF}-\kappa \mathrm{B}$ leading to the transcription of genes encoding cytokines, growth factors, and ECM proteins that are all closely related to diabetic nephropathy ${ }^{24)}$. Various anti-oxidants inhibit mesangial cell activation by HG and ameliorate features of diabetic nephropathy. The antioxidant NAC significantly inhibits HGinduced proliferation in mesangial cells ${ }^{25)}$. Consistent with this finding, Oryeong-san pretreatment significantly suppressed the HG-induced increase in ROS production and, consequently, inhibited mesangial cell proliferation.

\section{Conclusion}

Oryeong-san inhibits HG-induced cell proliferation by inhibiting the ROS-MAPK signaling pathway, which includes the regulation of cell-cycle related proteins such as cyclins/CDKs, p21 $1^{\text {waf1/cip1 }}$, and $\mathrm{p} 27^{\mathrm{kip} 1}$. In conclusion, Oryeong-san has a protective effect on renal proliferation, suggesting that Oryeongsan is beneficial traditional decoction in the treatment of mesangial cell proliferation leading to diabetic nephropathy.

\section{Acknowledgments}

This work was supported by grant of the Wonkwang University in 2012.

\section{References}


1. Jia H, Qi X, Fang S, Jin Y, Han X, Wang Y, Wang A, Zhou H. Carnosine inhibits high glucose-induced mesangial cell proliferation through mediating cell cycle progression. Regul Pept. 2009;154(1-3):6976.

2. Harding P, Balasubramanian L, Swegan J, Stevens A, Glass WF. 2nd. Transforming growth factor beta regulates cyclooxygenase-2 in glomerular mesangial cells. Kidney Int. 2006;69(9):1578-85.

3. Abrass CK, Peterson CV, Raugi GJ. Phenotypic expression of collagen types in mesangial matrix of diabetic and non-diabetic rats. Diabetes. 1988;37(12):1695702.

4. Sherr CJ. Cancer cell cycles. Science. 1996;274 (5293):1672-7.

5. Terada Y, Yamada T, Nakashima O, Tamamori M, Ito H, Sasaki S, Marumo F. Over-expression of cell cycle inhibitors (p16INK4 and p21Cip1) and cyclin D1 using adenovirus vectors regulates proliferation of rat mesangial cells. J Am Soc Nephrol. 1997;8 (1):51-60.

6. Terada Y, Inoshita S, Nakashima O, Yamada T, Kuwa-hara M, Sasaki S, Marumo F. Lovastatin inhibits mesangial cell proliferation via p27Kip1. J Am Soc Nephrol. 1998;9(12):2235-43.

7. Wolf G, Schroeder R, Zahner G, Stahl RA, Shankland SJ. High glucose-induced hypertrophy of mesangial cells requires p27(Kip1), an inhibitor of cyclindependent kinases. Am J Pathol. 2001;158(3):1091-100.

8. Borkemeyer D, Sorokin A, Dunn MJ. Multiple intracellular MAP kinase signaling cascade. Kidney Int. 1996;49(5):1187-98.

9. Liu QL, Sato S, Kishikawa T, Matsuzaki H, Yamanaka N. Effectiveness of a traditional Chinese medicine, Wulingsan, in suppressing the development of nephrocalcinosis induced by a high phosphorus diet in young rats. Med Electron Microsc. 2001;34(2): 103-14.

10. Yoshimura K, Miyake O, Okuyama A, Yoshioka T, Honda M, Yamaguchi S, Koide T. Effect of choreito and gorei-san on calcium oxalate crystallization in human urine. Hinyokika Kiyo. 1998;44(1):13-6.
11. He L, Rong X, Jiang JM, Liu PQ, Li L. Amelioration of anti-cancer agent adriamycin-induced nephritic syndrome in rats by Wulingsan (Gorei-San), a blended traditional Chinese herbal medicine. Food Chem Toxicol. 2008;46(5):1452-60.

12. Ahn YM, Cho KW, Kang DG, Lee HS. Oryeong-san (Wulingsan), a traditional Chinese herbal medicine, induces natriuresis and diuresis along with an inhibition of the renin-angiotensin-aldosterone system in rats. J Ethnopharmacol. 2012;141(3):780-5.

13. Ahn YM, Kho JH, Lee JY, Kang DG. Oryeongsan has different effects on water and electrolyte balance by routes of administration. Korean J. Oriental Physiology \& Pathology. 2012;26(3):338-43.

14. Foidart JB, Dechenne CA, Mahieu P, Creutz CE, Mey $\mathrm{J}$ de. Tissue culture of normal rat glomeruli. Isolation and morphological characterization of two homogeneous cell lines. Invest. Cell Pathol. 1979; 2(1):15-26.

15. Kapur R, Chandra S, Cooper R, McCarthy J, Williams A. Role of p38 and ERK MAP kinase in proliferation of erythroid progenitors in response to stimulation by soluble and membrane isoforms of stem cell factor. Blood. 2002;100(4):1287-93.

16. Yamagishi S, Fukami K, Ueda S, Okuda S. Molecular mechanisms of diabetic nephropathy and its therapeutic intervention. Curr Drug Targets. 2007;8(8): 952-9.

17. Tang D, He B, Zheng ZG, Wang RS, Gu F, Duan TT, Cheng HQ, Zhu Q. Inhibitory effects of two major isoflavonoids in Radix Astragali on high glucoseinduced mesangial cells proliferation and AGEsinduced endothelial cells apoptosis. Planta Med. 2011;77(7):729-32.

18. Kurogi Y. Mesangial cell proliferation inhibitors for the treatment of proliferative glomerular disease. Med Res Rev. 2003;23(1):15-31.

19. Wilmer WA, Dixon CL, Hebert C. Chronic exposure of human mesangial cells to high glucose environments activates the p38 MAPK pathway. Kidney Int. 2001; 60(3):858-71.

20. Liu W, Tang F, Deng Y, Li X, Lan T, Zhang X, 
Huang $\mathrm{H}$, Liu P. Berberine reduces fibronectin and collagen accumulation in rat glomerular mesangial cells cultured under high glucose condition. Mol Cell Biochem. 2009;325(1-2):99-105.

21. Parameswaran N, Nambi P, Hall CS, Brooks DP, Spielman WS. Adrenomedullin decreases extracellular signal-regulated kinase activity through an increase in protein phosphatase-2A activity in mesangial cells. Eur J Pharmacol. 2000;388(2):133-8.

22. Zhang L, Pang S, Deng B, Qian L, Chen J, Zou J, Zheng J, Yang L, Zhang C, Chen X, Liu Z, Le Y. High glucose induces renal mesangial cell proliferation and fibronectin expression through $\mathrm{JNK} / \mathrm{NF}$ $-\kappa \mathrm{B} / \mathrm{NADPH}$ oxidase/ROS pathway, which is inhibited by resveratrol. Int $\mathrm{J}$ Biochem Cell Biol. 2012;44(4):629-38.

23. Lin CL, Wang JY, Ko JY, Huang YT, Kuo YH, Wang FS. Dickkopf-1 Promotes Hyperglycemia-Induced Accumulation of Mesangial Matrix and Renal Dysfunction. J Am Soc Nephrol. 2010;21(1):124-35.

24. Ha H, Lee HB. Oxidative stress in diabetic nephropathy: basic and clinical information. Curr Diab Rep. 2001;1(3):282-7.

25. Yin D, Yao W, Chen S, Hu R, Gao X. Salidroside, the main active compound of Rhodiola plants, inhibits high glucose-induced mesangial cell proliferation. Planta Med. 2009;75(11):1191-5. 